Annals of Spiru Haret University.

Economic Series

Since 2000

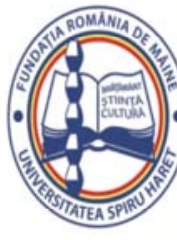

Issue 1/2019

\title{
IMPROVING TAX ADMINISTRATION THROUGH TECHNOLOGY INNOVATION IN NIGERIA (A STUDY OF FEDERAL INLAND REVENUE SERVICE)
}

\author{
Gbadegesin Babatunde ADEYEYE ${ }^{1}$ \\ ${ }^{1}$ Department of Accounting, University of Lagos, Akoka, Lagos, Nigeria \\ Email: gadeyeye@unilag.edu.ng
}

How to cite: ADEYEYE, G. B. (2019). "Improving Tax Administration through Technology Innovation in Nigeria (A Study of Federal Inland Recenue Service).” Annals of Spiru Haret University. Economic Series, 19(1), 31-63, doi: https://doi.org/10.26458/1913

\begin{abstract}
This study investigates the impact of technology innovation on tax administration in Nigeria. Primary Data were collected through the use of structured questionnaire administered on 219 staffers of Federal Inland Revenue Service (FIRS) to elicit their responses. Descriptive statistics, Analysis of Variance (ANOVA) and Regression Model were used for the data analysis. The $R$ value depicts that the use of information technology accounted for (76.3\%) improvement in tax administration in Nigeria. The results strongly support the $T P B$ in predicting the intention of users to adopt electronic tax-filing systems. The results also demonstrate the significant effect that computer self-efficacy has on behavioural intention through perceived ease of use, perceived usefulness, and perceived risk of use. Based on the findings of this study, implications for electronic tax filing are discussed. Finally, conclusion and recommendations were made based on the findings of the study.
\end{abstract}

Keywords: tax administration; technology innovation; FIRS; TPB; Nigeria

JEL Classification: H21 


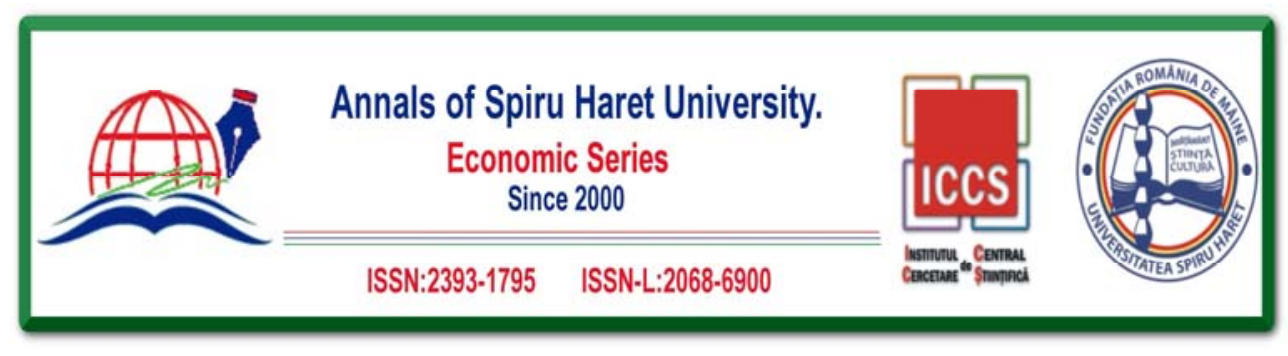

Issue 1/2019

\section{Introduction}

\subsection{Background to the Study}

The extent of development attainable by any nation is a function of its revenue generation power for the provision of infrastructure [Ogbonna \& Appah, 2012]. Basically, in Nigeria, government's sources of revenue to perform the functions of the state are derived from both tax and non-tax revenue sources [Omolehinwa \& Naiyeju, 2011]. However, Ogbonna and Appah (2012) posited that there is the need for a well-structured tax system for a country to attain the requisite infrastructural feature. Nzotta (2007) opined that taxes constitute key sources of revenue to the federation account shared by the federal, state and local governments.

Taxation is a major source of government revenue all over the world [Adeyeye, 2013; Ogbonna \& Appah, 2012]. Anyanfo (1996) stated that taxes are imposed to regulate the production of certain goods and services, protection of infant industries, control business and curb inflation, and to reduce income inequalities amongst others. It has also been stated that tax is a compulsory levy imposed on a subject or upon his property by the government to provide security, social amenities and create conditions for the economic well-being of the society [Appah, 2004; Adeyeye, 2013]. Tosun \& Abizadeh (2005) opined that taxes are used as proxy for fiscal policy and outlined five possible mechanisms by which taxes can affect economic growth. First, taxes can inhibit investment rate through such taxes as corporate and personal income, capital gain taxes. Second, taxes can slow down growth in labour supply by disposing labour leisure choice in favour of leisure. Third, tax policy can affect productivity growth through its discouraging effect on research and development expenditures. Fourth, taxes can lead to a flow of resources to other sectors that may have lower productivity. Finally, high taxes on labour supply can distort the efficient use of human capital high tax burdens even though they have high social productivity.

The history of taxation in Nigeria dates back to the pre-colonial era during which there were different systems of taxation existing in the forms of compulsory services, contribution of goods, money, labour and the likes, among the various kingdoms and ethnic groups and tribes controlled by the Emirs, Obas, Baales and the elders council in the Igbo land, in order to sustain the Monarch and also for community developpment [Institutes of Chartered Accountants of Nigeria (ICAN), 2010].

However, unlike the developed nations of the world such as the United States of America and the United Kingdom, non-tax revenue from the sale of crude oil has 32 


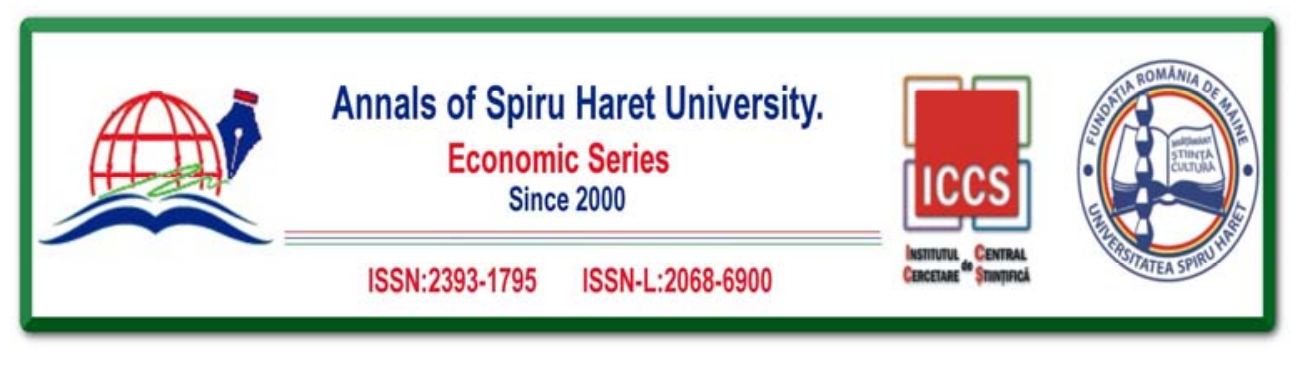

Issue 1/2019

constituted the major source of revenue to finance government operations in Nigeria. The non-oil revenue generated between 2004 and 2013 accounted for only $14 \%, 14 \%, 11 \%, 21 \%, 17 \%, 34 \%, 26 \%, 20 \%, 25 \%$ and $30 \%$ respectively of the total Federation Account consolidated revenue [CBN Annual Report, 2013].

Tax laws are enacted to impose taxes. The tax laws in operation in Nigeria include the Companies Income Tax Act (Cap. C21, LFN 2004), which imposes tax on the incomes of companies other than corporation soles and companies engaged in petroleum operations (upstream operations); the Petroleum Profits Tax Act (Cap. P13, LFN 2004), which imposes tax on the profits of companies engaged in petroleum operations; Education Tax Act (Cap. E4, LFN 2004), which imposes education tax on the assessable profits of companies registered in Nigeria; Personal Income Tax Act (Cap. P8, LFN 2004 as amended by Personal Income Tax (Amendment) Act, 2011), which imposes tax on incomes of individuals and corporation soles; Value Added Tax Act (Cap. VI, LFN 2004), which imposes tax on the supply and consumption of goods and services (except those specifically exempted or zero rated), made by incorporated companies and other business organisations; Stamp Duties Act (Cap. S8 LFN 2004); and Capital Gains Tax Act (Cap. C1 LFN 2004), which imposes tax on capital gains arising from the disposal of chargeable assets [Institute of Chartered Accountants of Nigeria, 2009].

The default of tax laws by the taxpayer constitutes non-compliance which is a serious challenge facing income tax administration and hinders tax revenue performance in Nigeria, as it is in some other developing countries of the world [Alabede, Ariffin \& Idris, 2011]. Hence, the vision of all revenue authorities is to promote compliance within the provisions of the tax laws and to ensure responsible enforcement by the revenue authorities so as to maximised tax revenue, thereby contributing to the economic development of the country [Nel, 2004]. The main issue faced by all tax authorities is that it has never been easy to persuade all taxpayers to comply with the regulations of a tax system regardless of time and place [Berhane, 2011]. A tax administration that encourages voluntary compliance resolutely and legally enforces compliance, treats the taxpayer as partner, rewards pro-tax behaviour and operates in an environment of accountability is a preferred tax system [Edemode, 2009]. Throughout the years, the tax administrators have been constantly concerned about developing new ways of improving institutional performance by increasing the effectiveness of tax control and providing taxpayer services that may allow them to better comply with their tax obligations [Nelson, 
Issue 1/2019

2002]. One of those ways by which this is done in Nigeria is the use of technology innovation for tax administration. According to Fu, Farn, and Chao (2006), the tax authorities considered electronic tax filing to be an opportunity to re-engineer tax process, making it easier, faster, and error free.

In any nation, the traditional and most widespread method of submitting income tax returns for tax authorities has been manual [OECD, 2011].

The Federal Inland Revenue Services recently launched Integrated Tax Administration System (ITAS). The ITAS has about nine modules, amongst which is project Joint Tax Board Tax Identification Number (JTB-TIN). It also involves the deployment of the Standard Integrated Government Tax Administration Solution (SIGTAS) and hardware infrastructure including support service for FIRS. This platform will enable the taxpayer file annual return and make payment online from their comfort zone without delay. The SIGTAS solution is expected to integrate some existing FIRS Enterprise Resource Planning (ERP) Production System applications like SAP (HR) for Human Capital Management Systems including: Online Appraisal, Leave, Payroll and Personnel Administration to mention just four. SAP (FICO) i.e., Finance \& Control/Material Management for Finance \& Accounts Systems including: Invoicing, Treasury Operations and Central Pay Offices (CPO), and SAP Self Service (ESS/MSS) Portal for Employee and Manager respectively.

\subsection{Statement of the Problem}

Tax administration in Nigeria has been plagued with problems, most of which can be attributed to the lack of or inadequate application of Information Technology in tax administration. This is why Odusola (2006) stated that the system in Nigeria is lopsided.

In Nigeria, tax authorities have not fully embraced the use of Information Technology to increase tax revenue and for record keeping. BECANS Business Environment Report (2007) argued that taxpayer's records in the database of tax authorities are manually compiled. Manual compilation involves the use of files/ folders for data storage. When records are stored in this manner over a long period of time, retrieval of such records can prove to be very difficult. Records stored in this manner can be very unreliable as these records are easily prone to manipulations. Furthermore, the records are exposed to danger of fire and flood. Method of tax return filing can be seen as another problem in tax administration in Nigeria. In practice, taxpayers are compelled to visit tax offices in order to file returns. 34 


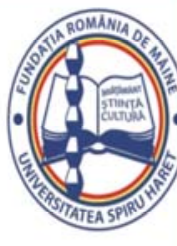

Issue 1/2019

Taxpayers may not be required to visit the income tax office for tax compliancerelated matters if there is efficient and effective Information Technology System (ITS) in place. This will enable taxpayers to meet their normal tax obligations in a convenient manner without visiting Income Tax Office. The above identified problem is what this study is set out to address.

\subsection{Aim and Objectives of the Study}

This study aimed at investigating the impact of technology innovation on tax administration in Nigeria. The following objectives are set to be achieved in line with the aim of the study:

i) determine the extent to which the use of information technology improves effective tax administration in Nigeria;

ii) ascertain how the use of information technology reduces inefficiency in tax administration in Nigeria;

iii) examine the perceived risk of use of information technology in tax administration in Nigeria;

iv) examine the extent to which information technology is accepted in the administration of tax in Nigeria.

\subsection{Research Questions}

The following research questions are suggested to guide the study:

i. How does the use of information technology improve effective tax administration in Nigeria?

ii. In what way does the use of information technology reduce inefficiency in tax administration in Nigeria?

iii. To what extent is the perceived risk of usage affecting the use of Information technology in tax administration in Nigeria?

iv. To what extent has information technology been accepted in the administration of tax in Nigeria?

\subsection{Research Hypotheses}

Based on the objectives of the study, the following research hypotheses stated in null form were formulated to answer the above research questions:

$\mathbf{H}_{\mathbf{0 1}}$ : The use of information technology does not improve tax administration in Nigeria. 


\section{Issue 1/2019}

$\mathbf{H}_{\mathbf{0 2}}$ : The use of information technology does not reduce inefficiency in tax administration in Nigeria.

$\mathbf{H}_{\mathbf{0 3}}$ : Perceived risk of use does not affect the use of information technology in tax administration in Nigeria.

$\mathbf{H}_{\mathbf{0 4}}$ : The application of information technology has not been accepted in the administration of tax in Nigeria.

It is hoped that this work will form a major catalyst to stimulate the initiation of a proper legislative process that will regulate tax administration in Nigeria, particularly the Federal Inland Revenue Service. Furthermore, effective implementation of information technology in tax administration will be of immense benefit to tax authorities, taxpayers, students and researchers in tax administration and the country at large. With e-filing, taxpayers may spend less time and money preparing, printing, and mailing paper returns, as well as less resources following up on the status of their filings, payments, and refunds. This means that the tax administration becomes less intrusive in the business environment. This study focuses on the effect of information technology on the efficiency of tax administration in Nigeria. The scope of the study is limited to the activities of the Federal Inland Revenue Service as it is the body that is responsible for tax administration of the federal government in Nigeria.

This paper is arranged into five sections. Section one is the introduction as discussed above, Section two discusses some relevant literature in tax administration, the methodology used for the study is discussed in chapter three, analysis of data and presentation of results are discussed in chapter four while summary, conclusion, contribution to knowledge and recommendations are treated in chapter five.

\section{Literature Review}

\subsection{Conceptual Framework}

This section introduces the conceptual framework of taxation, the nature and scope of taxes in Nigeria. It presents the principles of taxation as equality and fairness, certainty, convenience, economy, simplicity, productivity, flexibility and diversity.

\section{Tax and Taxation}

A number of authors have defined tax in various ways, however, the most striking element of the numerous definitions is that it is a "compulsory levy" that is imposed on the income, profits, property, wealth and consumption of goods and 36 


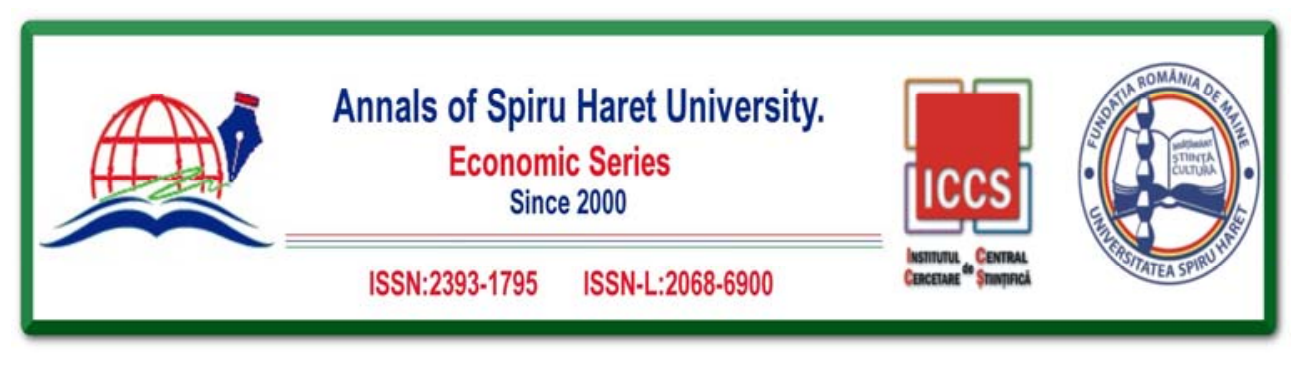

Issue 1/2019

services of citizens of a country (whether corporate entities or individuals) by the government of such country to enable government obtain the required revenue to provide basic amenities like road, school, and security for the well-being of the citizens [Soyode \& Kajola, 2006].

However, on the other hand, taxation may be broadly defined as the process or machinery by which communities or groups of persons are made to contribute in some agreed quantum and method for the purpose of the administration and development of the society [Ogundele, 1999]. From the various attempts to define tax, it can be concluded that taxation involves the pooling of economic resources from the taxpayers to the government for the purpose of achieving the objectives of the state.

\section{Nature and Scope of Taxes}

The main purpose of taxation and its product, tax, is to raise revenue to defray government expenditure and for the government to secure the lives and properties of the citizens against any external aggression or internal insurgencies within its jurisdiction [Adeyeye, 2013]. Nzotta (2007) posited that three important issues must be understood for taxation to play its required functions for the government in the society. First, a tax is a compulsory contribution made by the citizens to the government and this contribution is for general common use. Secondly, there is a presumption that the contribution to the public revenue made by the taxpayer may not be equivalent to the benefits received. Finally, a tax is not imposed on a citizen by the government because it has rendered specific services to him or his family. Thus, it is evident that a good tax administration plays many roles in the process of economic development of any country which Nigeria is not an exception [Appah, 2010]. A system of tax incentives and penalties may be designed to influence the efficiency of resource utilization; the distribution of the tax burdens plays a large part in promoting an equitable distribution of the fruit of economic development; the tax treatment of investment from abroad may affect the volume of capital inflow and rate of reinvestment of earnings there from; and the pattern of taxation on imports relative to that of domestic producers affect the foreign trade balance.

Nzotta (2007) noted that taxes generally have allocation, distributional and stabilization functions. The allocation function of taxes entails the determination of the pattern of production, the goods that should be produced, who produces them, the relationship between the private and public sectors and the point of social 


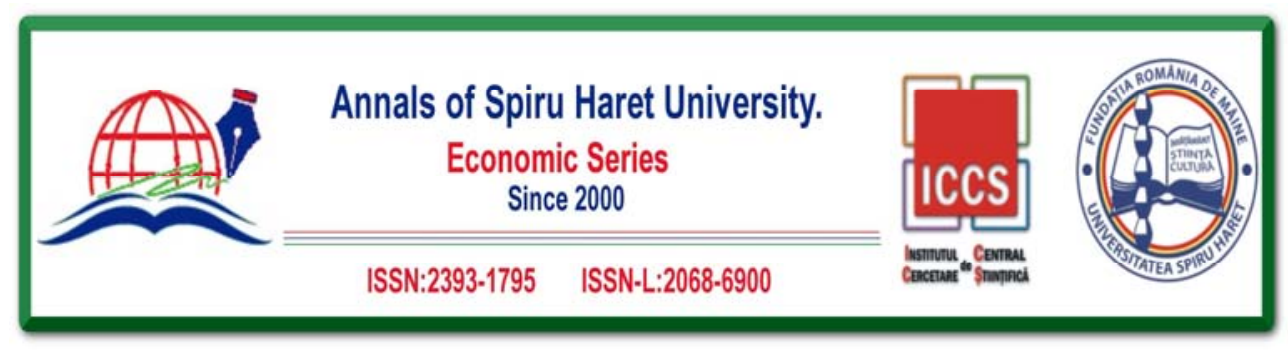

Issue 1/2019

balance between the two sectors. The distribution function of taxes relates to the manner in which the effective demand over economic goods is divided among individuals in the society. According to Anyanfo (1996), the principles of taxation mean the application of appropriate modality in the development and assessment of the tax structure. Such principles are essentially an application of some concepts derived from welfare economists. In order to achieve the broader objectives of social justice, the tax system of a country should be based on sound principles. A number of authors have highlighted the principles of taxation as equity and fairness, certainty, convenience, economy, simplicity, productivity, flexibility and diversity [National Tax Policy, 2016].

\section{The Nigerian Tax System}

Tax reform became necessary in Nigeria because of the nature of Nigerian tax structure. The dependence on oil revenue by all tiers of government in Nigeria has made it imperative for federal government to reform the existing tax laws. According to Alli (2009), the objectives of tax reforms in Nigeria include: to bridge the gap between the National Development needs and the funding of the needs; to ensure taxation, as a fiscal policy instrument, to achieve improved service delivery to the public; to improve on the level of tax derivable from non-oil activities; to ensure efforts at constantly reviewing the tax laws to reduce/manage tax evasion and avoidance; and to improve the tax administration to make it more responsive, reliable, skilful and taxpayers friendly; to reduce the complexity of the tax system both for the tax administrator and the taxpayer; to increase the confidence of the public on the tax system, thereby provoking voluntary compliance and to achieve other fiscal objectives. The Nigerian tax reform has experienced series of reforms since 1904 to date.

\section{Overview of the Recent Tax Reforms in Nigeria}

The tax reform of 2004 under the chairmanship of Ifueko Omoigui-Okauru marked a milestone improvement in tax administration in Nigeria. The achievements and progress made is one that has not been surpassed in the history of tax administration in Nigeria. The tax reforms of 2004 constitute an integral part of the National Economic Empowerment and Development Strategies (NEEDS).

The tax reform of 2004 was the outcome of recommendations made by the Study Group Report of 2002 and the Working Group Report of 2003 which 38 


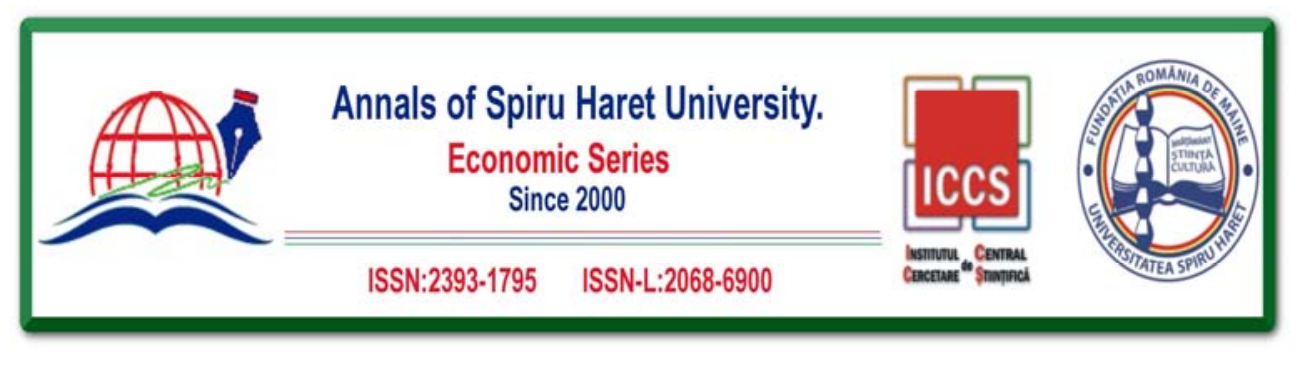

Issue 1/2019

reviewed the work of the former. Both groups made wide consultations after which they came out with nine bills that were presented by the federal executive council (FEC) to the national assembly for ratification. These bills are: the federal Inland Revenue Service Act 2004, personal income tax act 2004, petroleum profit tax act 2004, value-added tax act 2004, education tax act 2004, custom excise tariff etc (consolidation) Act 2004, National Sugar Development Act 2004 and National Automotive Council Act 2004.

Essentially, the study group of 2003 recommended that Nigeria needed national tax policy that is principally directed towards national development. Such national policy will constitute a means of attracting foreign direct investment, providing direction and focus on general tax practices, blending various opinions on taxes of different kinds as well as the issues surrounding those opinions, consolidation of several policy documents into a single document for easy reference [FIRS Hand Book, 2012].

On April 7, 2012 the national tax policy document was launched by President Goodluck Jonathan. Summarily, some of the salient provisions of the national tax policy are: the provision of a stable preference point for all stakeholders in the country on which they shall be held accountable, shifting the focus of the tax system from direct to indirect tax that is considered less distortionary, reducing the personal income tax from 25 per cent to 17.5 per cent, and company income tax from 30 to 20 per cent, strategically increasing VAT from 5 to 15 per cent, avoiding internal multiple taxation on income, property, imports, production and turnover by the various tiers of government, reducing and streamlining the number of tax incentives in the Nigeria tax system, collection of taxes only by career administrators that are public servants, thereby prohibiting the use of ad-hoc tax administrators, vesting of the power to impose, reduce, increase, review or cancel any rate of tax on the National Assembly, especially with respect to taxes from the executive, subjecting the Nigeria's tax system to comprehensive reviews every three years pertaining to existing tax legislations.

An essential component of the national tax policy is the introduction of taxpayers identification number (TIN). TIN was made possible by cooperation between the state and federal government. It is a nation-wide electronic base system for the registration and storage of data of tax payers in Nigeria. President Jonathan remarked that TIN by revolutionizing tax administration in Nigeria will expand the country's 


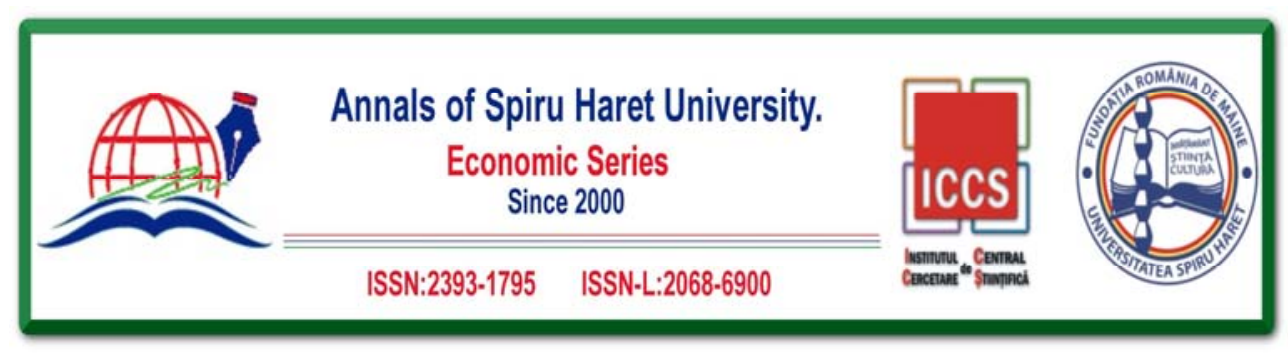

Issue 1/2019

tax base and increased the opportunity for tax generated revenue. He further remarked that TIN will modernize tax administration in Nigeria and ensures it is in keeping with best global practices. Overall, the aim of the national tax policy is to have a nation and people that see taxation as a partnership with the government. It is believed that the partnership between the government and taxpayers will broaden the tax base by bringing into the tax net both the formal sector and the informal sector that has consistently been elusive to tax administrators. Other notable reforms with statutory revenue implications are the education tax which was introduced in the year 1994 through decree No. 7 and the personal income tax act of 14th June, 2011 through Nigeria official Gazette No. 115 volume 98. The PITA deleted sections 3 (1) (b) (ii)-(xii) of the personal income tax act of 2004 which provided employees with free tax allowances. This implies that free tax allowances are no longer practicable. This would have been a desirable and welcome development for state governments since it will broaden their tax base, but with increase in statutory relief allowances under PITA, the prospecting benefits may be defeated. Furthermore, another aspect of tax reform in Nigeria is the restructuring of Federal Inland Revenue Service (FIRS).The restructuring became imperative because of the understanding that the existing structure was ineffective, chaotic and was giving fillip to indiscipline and fraud, and had cause the government to lose huge amount of tax revenue. The intent was to supplant the existing structure with one that allows feedback from bottom to the top and also organized work around team. The first step in restructuring FIRS was to make tax collection a function of ICT. In addition, all the various VAT offices and the area tax offices (ATOs) were lumped together and renamed integrated tax office (ITOs). Furthermore, after wide and due consultation, the management of FIRS concluded that there are seven strategic pillars on which to hinge the tax reform agenda. These strategic flanks were funding/autonomy, capacity building (improve structure and staffing); process re-engineering; auditing oil/gas and large tax payers; tax payer education, strengthen investigation and enforcement, and automate tax collection [FIRS Handbook, 2012].

Essentially, the FIRS was granted autonomy in the year 2007 under the FIRS Act 2007. By this, it became independent in both funding and human resources, being free from civil service bureaucracy. Several other structural changes were made. For instance, new departments were created. Some of the newly created departments were: process operation department (POD); Audit department; Tax 40 


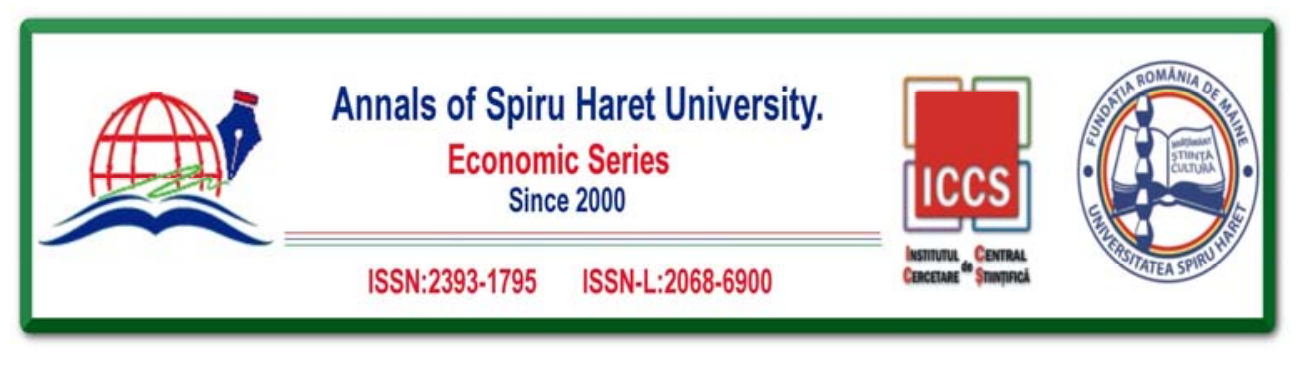

Issue 1/2019

policy research and development department (TPRD), Regional coordination department, modernization department etc. Each of these departments was assigned specific function, but collaboratively works towards the achievement of the reform agenda. As part of networking, group of departments was lumped together, and headed by directors that report directly to the executive chairman of FIRS.

The Federal Inland Revenue Service (Establishment) Act 2007 established the tax appeal tribunal to resolve disputes arising from the act, as well as the administration of the legislation listed in the first schedule to the act. In June 2007, the Management of Federal Inland Revenue Service introduced the "group system" structure in which roles and functions cascade from the group levels to departmental levels down to unit levels and finally to individual levels. The restructuring that saw the introduction of the group system made away with "Divisions." Under the current arrangement, groups are headed by Coordinating Directors who report to the Executive Chairman. The groups consist of several departments headed by directors and the departments are comprised of units and sub-units down the line. The five groups that emerged from this are (i) Corporate Development Group (CDG); (ii) Support Services Group (SSG); (iii) Tax Operations Group (TOG); (iv) Compliance and Enforcement Group (CEG); and, (v) Chairman's Office Group (COG). However, towards realisation of the need to constantly strive for efficiency and higher performance in the drive for delivering continuous and sustainable flow of revenues to government, the management of the service in May 2015 carried out a review of the current organisational structure and consequently approved some changes to the structure. The amended structure is aimed at ensuring that each and every officer of the service is assigned a job schedule with clearly agreed performance criteria which is smart and on which officers will be regularly assessed for performance. The new structure retains the five (5) Group arrangements with an inclusion of the office of Senior Special Assistant (SSA) which will have responsibility for supervision and coordination of all Direct reports to the Executive Chairman. The five (5) groups are now to be known as Domestic Taxes Group (DTG), Compliance Support Group (CSG), Enforcement Support Group (ESG), Modernisation Support Group (MSG), and Support Services Group (SSG).

The modernization Support Group (MSG) will continue to coordinate all modernisation initiatives, alongside the development of information and communication technology to facilitate prompt tax delivery services. 


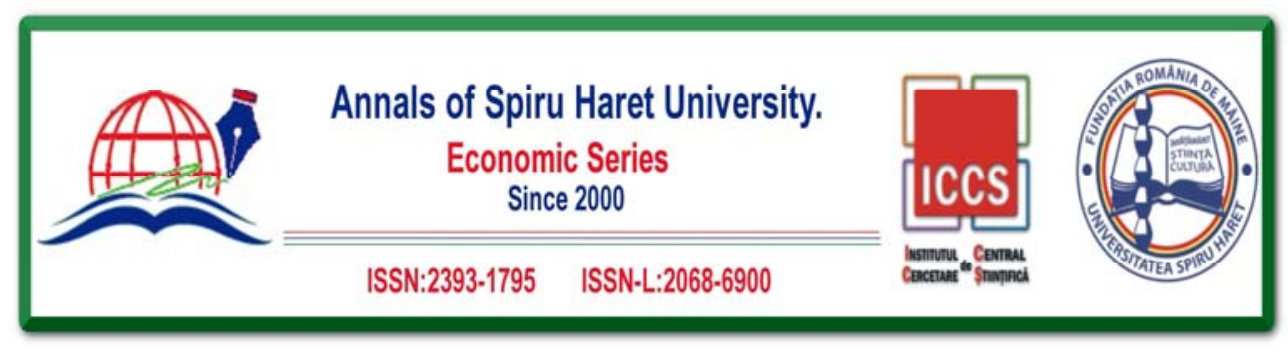

Issue 1/2019

The Modernisation Support Group of the FIRS

Against the background of the resolve to modernise the FIRS in other to remain relevant and virile in the face of economic realities, the Service adopted a program of reforms along seven strategic flanks. These include: Funding FIRS/Acquiring autonomy; Strengthening investigation/enforcement; Auditing oil, gas and large taxpayers; Providing taxpayer education and services; Re-engineering and automate collections/tax administration system; Building capacity in the areas of structure, staffing and specialization; and, Re-engineering and automating human resource processes, finance and procurement. These were followed by aggressive anticorruption campaign, revised code of ethics and performance management/result orientation. The overall goal of the strategic flanks was to increase collection on a year-on-year basis by at least 25 percent relative to 2004 level. The development of strategic flanks further necessitated the need to have in place a structure that would drive the projects, programmes and initiatives that would transform the business processes of the Service to reflect modern realities.

The department's primary function is to provide a focused attention on all modernization projects. This has led to monumental changes and proposed initiatives in the operations of the Service, in particular, and tax administration in Nigeria, in general.

\section{Prior Study on Tax Administration and Technological Innovation}

Several empirical studies have been conducted on electronic tax filing. Fu et al. (2006) carried out the study of taxpayer intentions to accept electronic tax filing. Using the filing of personal income tax in Taiwan as an example of e-government services, the study found that taxpayers tend to concentrate on the usefulness of a tax-filing method and may be fairly pragmatic in developing general attitudes towards using the method. Lee (2008) studies the factors influencing the use of internet banking. In his work, TAM and PBC was adopted theory and found that internet banking is the most profitable e-commerce application over the last decade. Wang (2002) in his study title the adoption of electronic tax filing system also used TAM as a theoretical framework. He examines the effect of computer self-efficacy on the intention to use an electronic tax-filing system. Using factor analysis based on a sample of 260 users from a telephone interview, he suggested the need to extend TAM in predicting the intention of users to adopt electronic tax filing system. 


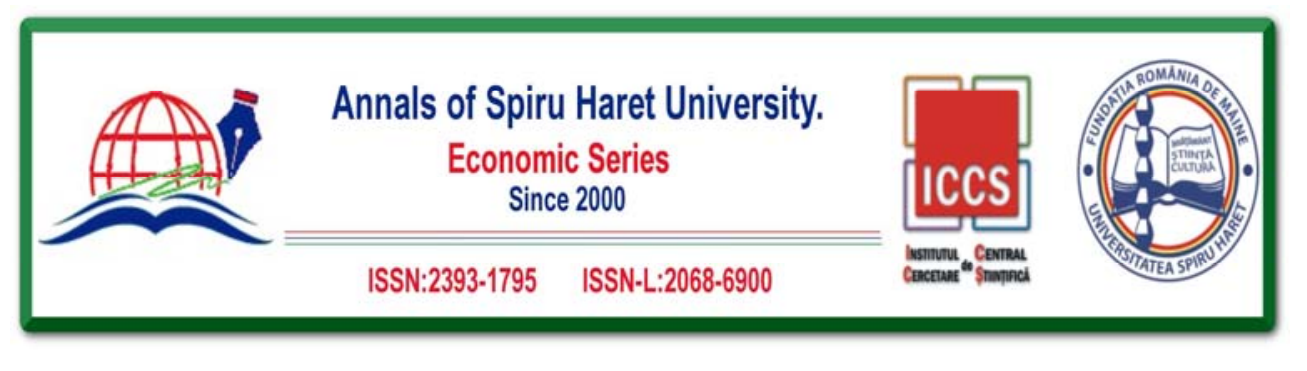

Issue 1/2019

\subsection{Theoretical Framework}

This current study is premised on Technology Acceptance Model (TAM) and Theory of Planned Behaviour (TPB). The two theories are well established in the information Technology (IT) arena and appear to be widely accepted [Riemenschneider, et al., 2003; Fu, et al., 2006]. TAM theorizes that an individual's intention towards using a system is jointly determined by perceived usefulness (PU), the user's "subjective probability that using a specific application system will increase his or her job performance" and perceived ease of use (PEOU), "the degree to which the user expects the target system to be free of effort." [Davis, 1989] The effects of external variables (e.g., system design characteristics) on behavioural intention (BI) are mediated by these beliefs. According to Davis, Bagozzi and Warshaw, (1989), PEOU also has a direct effect on PU. In predicting usage, TAM models might be useful within and across organizations for evaluating applications or technologies, or to make comparisons between user groups or applications, as suggested by [Adams, et al., 1992]. However, TAM has limitations in being applied beyond the workplace because its fundamental constructs do not fully reflect the variety of user task environment and constraints.

Paul and John (2003) suggested that TAM is a useful model but has to be integrated into a broader one which would include variables related to both human and social factors which the theory of planned behaviour (TPB) takes into account.TPB incorporates subjective norms (SN) and perceived behaviours control (PBC) as direct determinants of $\mathrm{BI}$ [Fu, et al., 2006]. Neither TAM nor TPB have been found to provide consistently superior explanations or predictions of behaviour in the past. A growing body of research has been focused on integrating them to predict usage intention from different viewpoints: Subjective Norms (SN) has been included as an additional predictor of intention for mandatory settings [Venkatech, et al., 2003]. In addition, using TPB as a basic structure, attitude is decomposed by incorporating PU and PEOU. The approach provides several advantages. First, it seems unlikely that belief structures will be consistently related to intention and that the relationships would become clearer and more readily understood. Second, by focusing on specific beliefs, the model becomes more managerially relevant, pointing to specific factors that may influence adoption and usage of new technology in tax administration. This is as explained below. 
Issue 1/2019

\section{Attitude and E-Tax Filing}

Several studies have examined the role of attitude on IT usage behaviour. The attitude variable was considered as a mediating variable that influences the BI and is affected by PU and PEOU. However, weak support of the relationship was found between the attitudes toward a specific IS and BI. Kay (1993) suggested that while measuring attitudes toward Information System usage, it is preferable to be more specific about the content of the attitude object. Fu et al. (2006) stated that the omission of attitude allows researchers to investigate the influence of PEOU and PU on BI. Thus, the "attitudes" factor is decomposed to simplify the model. Additionally, a link between PEOU and BI is included because empirical studies have found a significant relationship between them [Lu \& Gustafson, 1994].

\section{Perceived Behavioural Control (PBC) and E-Tax Filing}

The $\mathrm{PBC}$ construct refers to an individual's perceptions of the presence or absence of resources or opportunities necessary for performing an action. It is decomposed into both the internal notion of individual "self-efficacy (SE)" [Bandura, 1977] and to external resource constraints, similar to Triandis's (1977) facilitating conditions. SE is related to perceived ability. With respect to e-Tax usage, we anticipated that higher levels of SE would lead to higher levels of BI toward e-Tax. The facilitating conditions consist of two sub dimensions: resource factors (RFC), such as computer equipment, and technology issues (TFC), that may restrict usage. The absence of facilitating resources results in barriers to usage which may inhibit usage. Thus, a taxpayer might be unwilling to accept e-Tax if little or no computer equipment is available, and if technical support is low.

\section{Perceived Risk and E-Tax Filing}

Studies in consumer behaviour suggest that when engaging in an online transaction process, concerns of inherent risk have surfaced as salient to many potential users [Hoffman, et al., 1999]. However, actual risk is difficult to measure objectively, literature has therefore primarily addressed the notion of perceived risk (PR), defined here as the taxpayer's perception of the uncertainty and adverse consequence of a desired outcome. Perceived risk of online shopping has been shown to influence attitude towards online purchasing [Heijden, et al., 2001]. Taxpayers may be reluctant to file their tax return electronically if they perceive a lack of security in the process. 


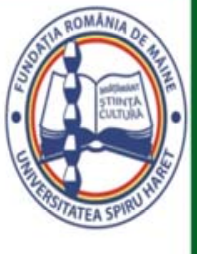

Issue 1/2019

Subjective norms and E-Tax filing

Ajzen (1991) described subjective norms as an individual's perception of what significant people around (e.g., family) would think about his or her performance of a particular behaviour. The theory predicts that an individual is tend to be more influenced if perceives that people around him or her think he or she should engaged in the behaviour [Randall \& Gibson, 1991]. Past empirical research in various fields showed that subjective norms could influence positively and significantly behavioural intention [see Bobek \& Hatfield, 2003; Park \& Blenkinsopp, 2009]. Venkatesh and Davis (2000) found that subjective norms had a significant influence on perceived usefulness and behavioural intentions when use of the technology was mandatory. When technology use was voluntary, subjective norms still influenced perceived usefulness but did not have a direct influence on behavioural intentions. Based on these findings in a voluntary context, we propose a similar outcome was expected in the present research that people will tend to use e-filing the more people around them want them to do so.

\section{Compatibility and E-Tax Filing}

Also included in our model is compatibility (CMP), which serves as an antecedent of PU. Compatibility, defined as the degree to which the technology fits the potential adopter's previous experience, work practice, and needs, has been identified as an essential factor for innovation adoption [Rogers, 1985]. Considerable number of research has reported in the past the significant effect of CMP on the user technology acceptance decision [Wu, et al., 2007]. A number of authors have explained the significant effect of CMP on attitude [Hung, et al., 2006; Hsu, et al., 2006]. In addition, Chau et al., (2001) found that CMP is a significant factor in determining PU but not PEOU. Individuals who find the use of paperless income tax filing for online services/internet based application to be consistent with their values, existing practices, preferred style and prior experience would prefer to use paperless e-filing system.

The adapted model is shown in Fig. 1. 


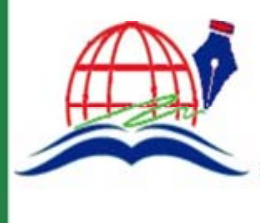

Annals of Spiru Haret University.

Economic Series

Since 2000
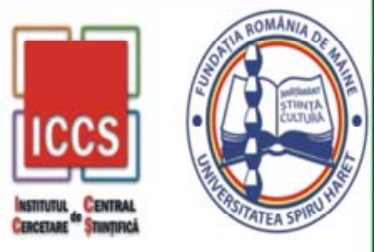

Issue 1/2019

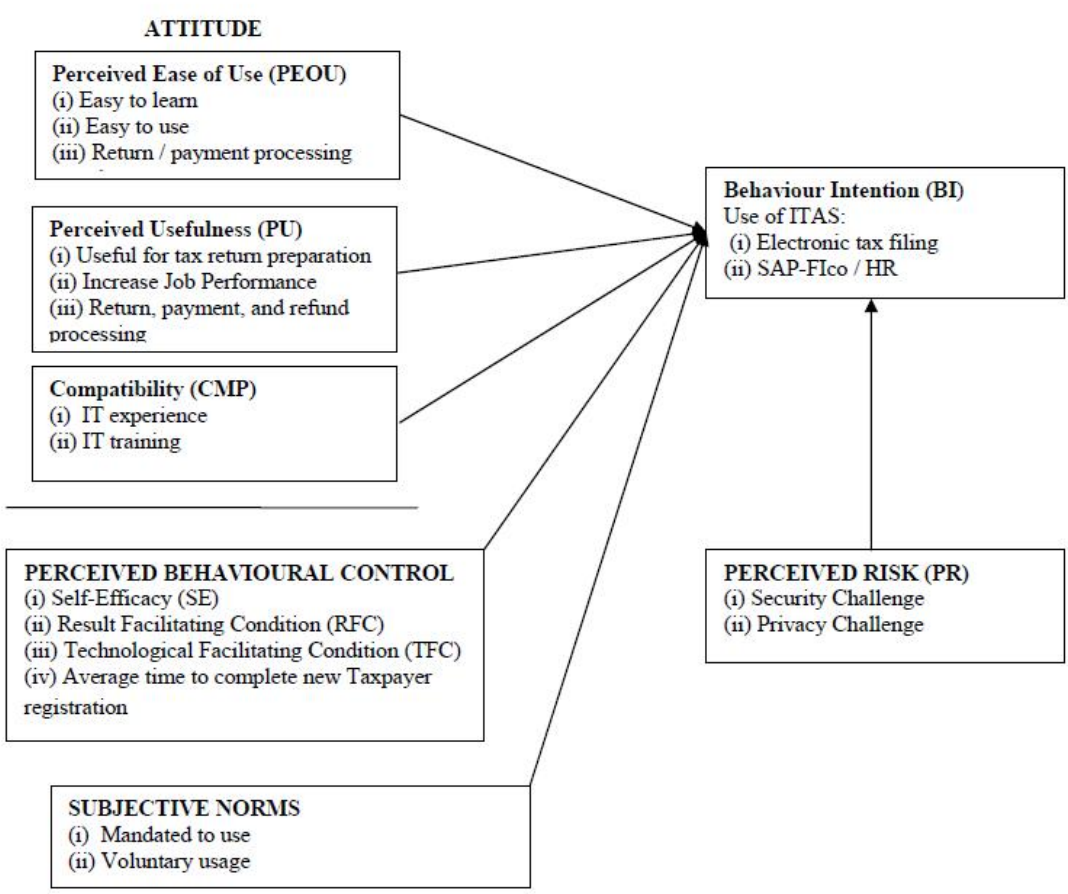

Fig. 1. Theory of Planned Behaviour (TPB) Model

Source: Adapted from Fu, et al. (2006) and modified by the authors (2018)

\section{Research Methods}

This section describes the research design, the characteristics of the population of the study, the sampling technique used to ensure a representative sample and the instruments of data collection. The study adopted cross sectional survey design for data gathering purpose. This approach enables the researcher to obtain information from a representative sample of the population. The population of this study comprises stakeholders in tax administration in Nigeria. It is made up of tax authorities (staff), the tax consultants, existing and potential taxpayers comprising individuals and corporate entities. For the purpose of this study, the target population 


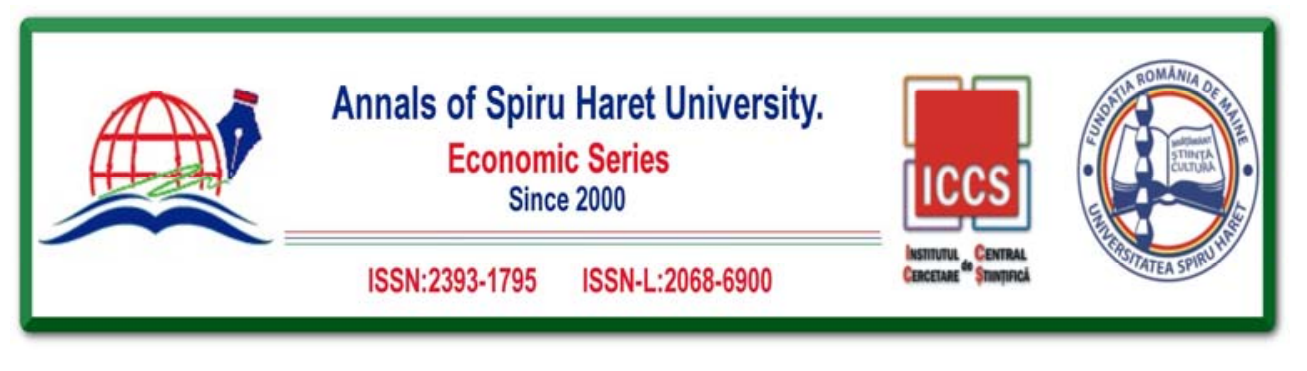

Issue 1/2019

is 6,500 staff of FIRS, tax consultants registered with FIRS, 770,407 corporate taxpayer and 1,393,590 individual taxpayers filing returns with FIRS. This population is considered to be appropriate because all the subjects of the population are stakeholders in tax administration in Nigeria. This study intends to make a generalization of its findings to all the stakeholders in Tax administration in Nigerian (the population of this study). Since a census (complete evaluation of the entire population) could not be done, the representativeness of the population was assured by using the Cluster sampling technique.

This technique is most appropriate where the concentration of the elements of the target population (in equitable proportion) can be reached within a clearly demarcated area. The areas adopted by this study are FIRS offices in the southwest region with 484 staff who attend to taxpayers and consultants on daily basis. The strength of this cluster is that there is a comprehensive sampling frame from which the sample respondents were scientifically drawn. FIRS offices are classified into Large Tax office (LTO), Medium Tax Office MTO, Micro and Small Tax Office (MSTO), Government Business Tax Office (GBTO). In addition to this classification, FIRS has units and department that contain reasonable number of staff that deal with taxpayer regularly in all regions across the geo political zones in Nigeria. These units/departments are Tax Audit Unit, Debt Management Office (DMO), and Taxpayer Service (TPS). Southwest region has all classes of offices within the classification in FIRS.

The researchers sampled all the offices located in southwest region in order to reduce the possible sample errors with exception of GBTO because they dealt with Ministries Departments and Agencies (MDAs) who are not taxpayer but agent of collection.

To achieve the stated objectives of this study, both primary and secondary sources of data were used. The primary data collection instrument used was a structured questionnaire divided into two sections. The first section contained items to capture the demographic data of the sampled respondents. Section two was designed to collect data on perceive behavioural attitude of staff of Federal Inland Revenue Service staff on various Technology Innovation for Human resources process and tax accounting, to examine the attitude of the taxpayer towards the use of information technology in tax administration and finally to identify the factors that influence the attitude, subjective norms, perceived behavioural control and intention of both taxpayer and staff towards the use of information technology in 


\section{Issue 1/2019}

tax administration. In constituting the sample for this study, 219 respondents were drawn from 484 staff in the offices located in Southwest region. 219 copies of questionnaire were administered in various offices during the general VAT gathering exercise carried out by FIRS in October 2017. During this exercise, copies of the questionnaire were distributed to all staff members from states in the South West. This exercise allows the staff to have one on one interaction with taxpayer to hear their view about tax administration. The simple random sampling technique was adopted using the random number table to draw the required respondents among the staff that participated in the exercise.

The construct validity of the research instrument was guaranteed by giving the research instrument to three (3) Senior Lecturers in Departments of Accounting and Business Administration to indicate the extent to which each of the questionnaire items is relevant to the underlying construct it indicates. This was done on a five point scale ranging from 'relevant' to 'not relevant'. Their evaluation was analysed using descriptive statistics. Items with a mean of less than 3.50 were removed while those with mean scores between 3.50 and 4.00 where reframed and those with mean scores above 4.00 were retained. This approach was adapted from the Mukasa (2011) study on tax compliance in Uganda with slight modifications.

\section{Variable Measurement}

The variables used in this study were measured by assigning numbers to items or observations. The level of measurement is known to be a function of the rules under which the numbers are assigned [Kothari, 2004]. Tax administration and the use of information technology in Federal Inland Revenue Service (FIRS) were correlated together to ascertain if any connection exists between them to test the Hypothesis one of this study. Tax Administration was measured by various functions in FIRS. The administrative effectiveness was measured by the corresponding amounts of revenue reported in the annual report, turn-around time in tax return processing, finance and accounting process of the FIRS. Use of information technology is the variable relevant to the Hypothesis two of this study. This was measured by asking respondents to indicate the extent to which they agree to the question items on various aspects to the e-filing tax system on a five-point Likert's scale, ranging from Strongly Disagree to Strongly Agree. Based on the various aspects of the use of e- 
filing that has been identified in past literature, these variables are: general degree of performance in income tax filing preparation, speed and time saving, computer knowledge and better management of information stored in electronic data base.

Risk is the variable relevant to the Hypothesis 3 of this study. Risk was measured by security challenges and privacy challenges by asking respondents to indicate the extent to which they agree to the items on various aspects to the tax administration on a five-point Likert's scale, ranging from Strongly Disagree to Strongly Agree. Staff Training, Attitude, Self-Efficiency are the variables relevant to the Hypothesis 4 of this study. These are measured by asking respondents to indicate the extent to which they agree to the question items on various aspects of the tax administration on a five-point Likert's scale, ranging from Strongly Disagree to Strongly Agree.

Regression Analysis was used to establish the relationship between the technology innovation and tax administration of the FIRS. The Analysis of Variance (ANOVA) was used to test three hypotheses on the variables of the TPB and e-filing. The regression analysis was subsequently used to analyse the extent to which each of these variables (attitude, perceived behavioural control, subjective norms and perceived risk) influence the respondents' intention to use electronic tax filing system. SPSS version 20.0 was used for the purpose of analysing the data. A perceived limitation to this study is that only data collected from FIRS staff were used upon which the findings were generalised. It is possible that other State Internal Revenue Service with low tax drive may have contrary opinion if given opportunity to respond to some of the questions. However, the identified limitation is not expected to have adverse effect on the outcome of the study.

\section{Data Analysis and Presentation of Results}

This section covers the analysis of data and findings from the study. The total copies of questionnaire administered, that is, two hundred and nineteen (219) were appropriately completed and returned because of the approach used in administering the questionnaire.

The demographic characteristics of the respondents (i.e. Tables and explanations of each demographic result) were not included since the attributes were not used in the test of hypotheses. 
Issue 1/2019

Descriptive Statistics and Tests of Hypotheses

This study aimed at investigating the impact of technology innovation on tax administration in Nigeria. The tests were carried out at 0.05 level of significance. The decision to accept or reject the null hypothesis is based on the p-value, the decision rule which states that when the p-value is less than the level of significance, the alternative hypothesis should be accepted but when the p-value is higher than the level of significance, the null hypothesis should be accepted.

NB: Descriptive statistics Tables are not presented in the body of the paper in order to optimise the maximum pages allowed by the Journal. However, in this section, research hypotheses structured in null form are analysed using regression model, analysis of variance (ANOVA) and correlation coefficients. The tests of the hypotheses are presented in the following sub-sections.

Research Question 1: How does the use of information technology improve effective tax administration in Nigeria?

Test of Hypothesis

$\mathrm{H}_{01}$ : The use of information technology does not improve tax administration in Nigeria.

Table 1. Model Summary

\begin{tabular}{|l|r|r|r|r|}
\hline Model & $\mathrm{R}$ & R Square & Adjusted R Square & Std. Error of the Estimate \\
\hline 1 & $0.763^{\mathrm{a}}$ & 0.581 & 0.576 & 0.03844 \\
\hline
\end{tabular}

a. Predictors: (Constant), Automation of Finance \& Account related function, Automation of unified communication \& enterprise collaboration, implementation of customer service call centre

Source: Field Survey, 2018

From the regression analysis result shown in Table 1, it was found that in the model summary table, the $\mathrm{R}$ value is 0.763 , R-square is 0.581 , adjusted $\mathrm{R}$-square is 0.576 and the standard error of estimate is 0.03844 . The large value of $\mathrm{R}$ indicates a stronger relationship between the observed and predicted values of the variables. In other words, the $\mathrm{R}$ value depicts that the use of information technology accounted for 76.3\% improvement in tax administration in Nigeria. This implies that the proportion 


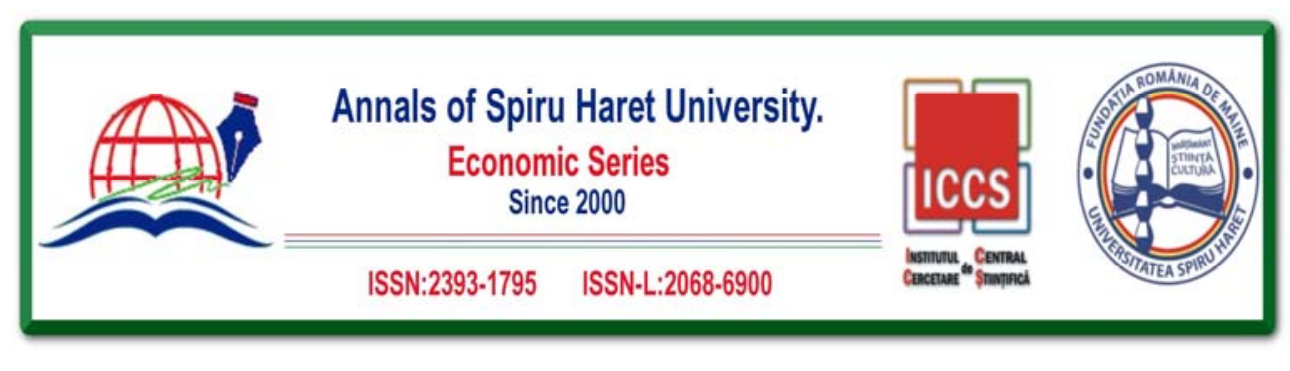

Issue 1/2019

of variation in the dependent variable is explained by the regression model. Hence, the value of R-square (58.1\%) indicated that the model properly fits the data. More so, the value of adjusted $\mathrm{R}(57.6 \%)$ showed that the value of R-square closely reflected the goodness of fit of the model in the population.

Table 2. ANOVA ${ }^{\mathrm{a}}$

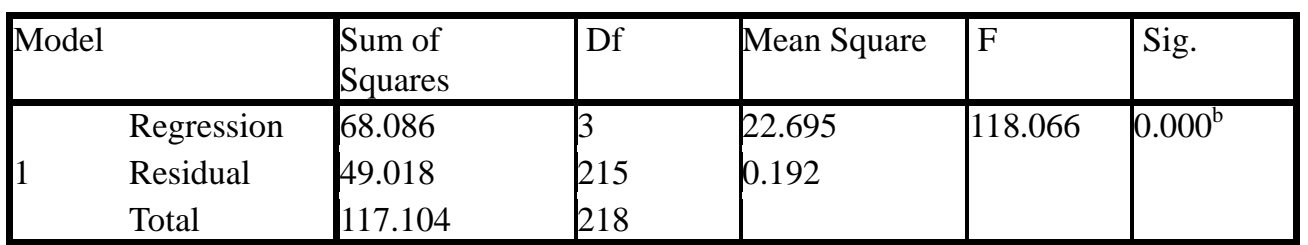

a. Dependent Variable: improve tax administration

b. Predictors: (Constant), Automation of Finance \& Account related function, Automation of unified communication \& enterprise collaboration, implementation of customer service call centre

\section{Sources: Field Survey, 2018}

Furthermore, the analysis of variance table (ANOVA), Table 2, showed regression sum of square value of 68.086 which is higher than the residual sum of square value of 49.081. This implies that the model accounted for most of the variations in the dependent variable. More so, the F calculated value of 118.066 is greater than the tabulated value of 3.90 , indicating a significant relationship. In addition, the significant value of $\mathrm{P}(0.000)$ is smaller than $(0.05)$ which means that the independent variable (use of information technology) to a high extent accounted for the variations in the dependent variable (tax administration). Hence, we posited that there is significant relationship between the use of information technology and tax administration in Nigeria. Table 3 shows the model coefficient (that is, the intercept and the slope). From Table 3, the results show that automation of finance \& account related function (t-value $=6.702$, p-value $=0.000$ ) is significant at $5 \%$ level. Hence, one additional increase in automation of finance \& account related function will bring about $59.7 \%$ improvements in tax administration. The result on automation of unified communication and enterprise collaboration $(\mathrm{t}$-value $=5.611, \mathrm{p}$-value $=$ 0.000 ) is significant at $5 \%$ level. This implies that an increase in automation of unified communication and enterprise collaboration will bring about $44.7 \%$ improvements in tax administration. The result also shows that implementation of customer service call centre $(\mathrm{t}$-value $=1.746, \mathrm{p}$-value $=0.082)$ is positively 
Issue 1/2019

correlation but not significant at 5\% level. This implies that an increase in implementation of customer service call centre will bring about $24.9 \%$ improvements in tax administration. These analyses signify that each of the variables has contributed to improved tax administration in Nigeria. Hence, the use of information technology does improve tax administration in Nigeria.

Table 3. Coefficients ${ }^{\mathrm{a}}$

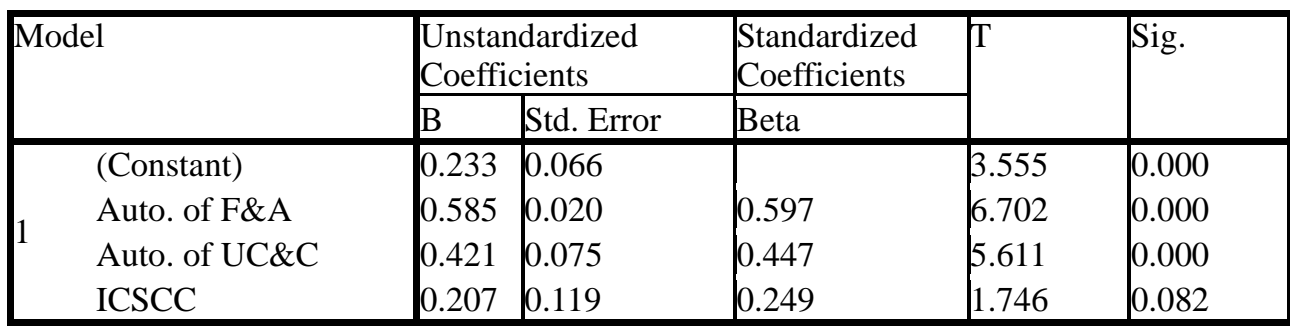

a. Dependent Variable: reduction in workers’ productivity

Sources: Field Survey, 2018

Research Question 2: In what way does the use of information technology reduces inefficiency in tax administration in Nigeria?

Test of Hypothesis

$\mathrm{H}_{02}$ : The use of information technology does not reduce inefficiency in tax administration in Nigeria. This research hypothesis is analysed thus:

Table 4. Model Summary

\begin{tabular}{|l|r|r|r|r|}
\hline Model & \multicolumn{1}{|c|}{$\mathrm{R}$} & \multicolumn{1}{|c|}{ R Square } & Adjusted R Square & $\begin{array}{c}\text { Std. Error of the } \\
\text { Estimate }\end{array}$ \\
\hline 1 & $0.960^{\mathrm{a}}$ & 0.921 & 0.920 & 0.02835 \\
\hline
\end{tabular}

a. Predictors: (Constant),TIN Reg, electronic Tax Filing, VAT Collection, SAP-HR/FICO

Source: Field Survey, 2018 


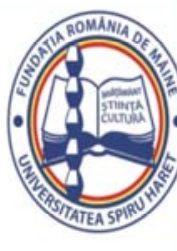

Issue 1/2019

From the regression analysis result shown in Table 4, it was found that $\mathrm{R}$ value is (0.960), R square (0.921) adjusted $\mathrm{R}$ square (0.920) and the standard error of estimate is (0.02835). The large value of $\mathrm{R}$ indicates a stronger relationship between the observed and predicted values of the variables. The $\mathrm{R}$ value depicts that the use of information technology reduces inefficiency in tax administration (96.0\%). This implies that the proportion of variation in the dependent variable is explained by the regression model. The value of R-square (92.1\%) indicated that the model properly fits the data. More so, the value of adjusted R (92.0\%) showed that the value of R square closely reflected the goodness of fit of the model in the population.

Table 5. ANOVA ${ }^{\mathrm{a}}$

\begin{tabular}{|l|l|l|l|l|l|}
\hline \multicolumn{1}{|c|}{ Model } & \multicolumn{1}{c|}{ Sum of Squares } & \multicolumn{1}{|c|}{ Df } & \multicolumn{1}{c|}{ Mean Square } & \multicolumn{1}{c|}{ F } & \multicolumn{1}{c|}{ Sig. } \\
\hline Regression & 108.747 & 4 & 27.187 & 626.282 & 0.00 \\
1 Residual & 9.290 & 214 & 0.043 & & $0^{\mathrm{b}}$ \\
Total & 118.037 & 218 & & & \\
\hline
\end{tabular}

a. Dependent Variable: Inefficiency in tax administration

b. Predictors: (Constant), TIN Reg, Internet Tax Filing, VAT Collection, SAP-HR/FICO

Source: Field Survey, 2018

Table 6. Coefficients ${ }^{\mathrm{a}}$

\begin{tabular}{|c|c|c|c|c|c|}
\hline \multirow[t]{2}{*}{ Model } & \multicolumn{2}{|c|}{$\begin{array}{l}\text { Unstandardized } \\
\text { Coefficients }\end{array}$} & $\begin{array}{l}\text { Standardized } \\
\text { Coefficients }\end{array}$ & \multirow[t]{2}{*}{$\mathrm{T}$} & \multirow[t]{2}{*}{ Sig. } \\
\hline & $\mathrm{B}$ & Std. Error & Beta & & \\
\hline (Constant) & 0.452 & 0.087 & & 5.174 & 0.000 \\
\hline TIN Reg. & 0.432 & 0.050 & 0.481 & 5.896 & 0.000 \\
\hline Internet Tax Filing & 0.502 & 0.042 & 0.503 & 5.530 & 0.008 \\
\hline VAT Collection. & 0.813 & 0.032 & 0.847 & 15.768 & 0.000 \\
\hline SAP-HR/FICO & 0.158 & 0.065 & 0.196 & 2.439 & 0.016 \\
\hline
\end{tabular}

a. Dependent Variable: Inefficiency in tax administration

Source: Authors Computation, 2018 


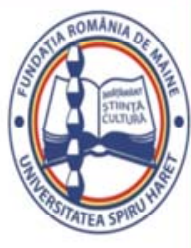

\section{Issue 1/2019}

Table 5 presents the analysis of variance (ANOVA) Table which tests the significance or otherwise the fitted of the model. The F calculated is (626.282), while the $\mathrm{F}$ tabulated obtained from the statistical table at 0.05 level of significance is 2.42 . Since the F-calculated (626.282) is greater than the table value of F (2.42), the null hypothesis that "The use of information technology does not reduce inefficiency in tax administration in Nigeria" is rejected. It is thereby concluded that the use of information technology will reduce inefficiency in tax administration in Nigeria.

Results obtained from Table 6 reveals that the magnitude of the beta coefficient for Tax Identity Number (TIN) registration is significant at $5 \%$ for the total sample. The result implies that for one additional use of TIN registration reduces tax administration inefficiency by $48.1 \%$. Hence FIRS may consider widening the Tax payer Identity Number (TIN) registration to expand the country's tax base and increased the opportunity for tax generated revenue. It is also found that the result on electronic tax filing is positively correlated with tax administration. The result reveals that an increase in electronic tax filing will bring about 50.3\% reductions in tax administration inefficiency. The result on value added tax (VAT) collection shows a positive correlation between business performance and group membership. The magnitude of beta coefficient for VAT collection is statistically significant at $5 \%$ for the total sample. The result shows that VAT collection reduces tax administration inefficiency by $84.7 \%$. Finally, Table 6 shows that the magnitude of beta coefficient for SAP-HR/FICO is significant at $5 \%$ for the total sample. The result implies that for one additional use of SAP-HR/FICO reduces tax administration inefficiency by $19.6 \%$. Hence FIRS may consider the implementation of SAP-HR/FICO to enable better management of personnel budgets and respond to evolving organizational requirements.

Research Question 3: To what extent is the perceived risk of usage affect the use of Information technology in tax administration in Nigeria?

Test of Hypothesis

$\mathrm{H}_{03}$ : Perceived risk of use does not affect the use of information technology in tax administration in Nigeria. 


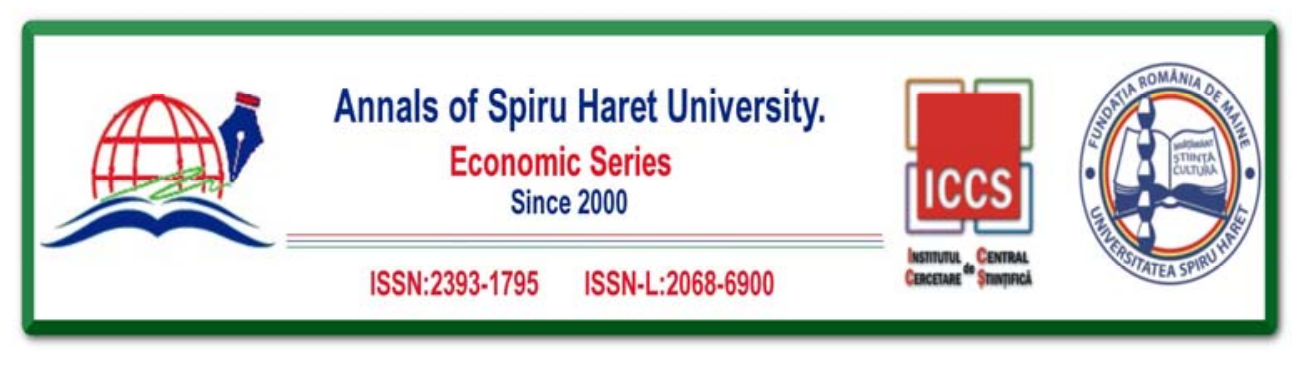

Issue 1/2019

Table 7. Model Summary

\begin{tabular}{|l|r|r|r|r|}
\hline Model & \multicolumn{1}{|c|}{ R } & R-Square & Adjusted R- Square & $\begin{array}{c}\text { Std. Error of the } \\
\text { Estimate }\end{array}$ \\
\hline 1 & $0.959^{2}$ & 0.919 & 0.918 & 0.02026 \\
\hline
\end{tabular}

a. Predictors: (Constant), security challenge, privacy challenge

Source: Field Survey, 2018

From the regression analysis result shown in Table 7, it was found that $\mathrm{R}$ value is 0.959 , R-square equals 0.919 , adjusted R-square equals 0.918 and the standard error of estimate is 0.02026 . The large value of $R$ indicates a stronger relationship between the observed and predicted values of the variables. The $\mathrm{R}$ value depicts that the perceived risk of use affect the use of information technology in tax administration in Nigeria by $95.9 \%$. This implies that the proportion of variation in the dependent variable is explained by the regression model. The value of R-square (91.9\%) indicated that the model properly fits the data. More so, the value of adjusted R (91.8\%) showed that the value of R-square closely reflected the goodness of fit of the model in the population.

Table 8. ANOVA ${ }^{\mathrm{a}}$

\begin{tabular}{|ll|l|l|l|c|c|}
\hline \multicolumn{1}{|c|}{ Model } & Sum of Squares & Df & Mean Square & F & Sig. \\
\hline \multirow{4}{*}{1} & Regression & 108.488 & 2 & 54.244 & 227.007 & $0.000^{\mathrm{b}}$ \\
& $\begin{array}{l}\text { Residual } \\
\text { Total }\end{array}$ & 9.549 & 216 & 0.044 & & \\
\hline
\end{tabular}

a. Dependent Variable: Perceived risk of use of information technology

b. Predictors: (Constant), security challenge, privacy challenge

Source: Field Survey, 2018

Table 8 presents the analysis of variance (ANOVA) Table which tests the significance or otherwise the fitted of the model. The F calculated is 227.007, while the F tabulated obtained from a statistical table at 0.05 level of significance is 3.04. 


\section{Issue 1/2019}

Since the F-calculated (227.007) is greater than the table value of F (3.04), the null hypothesis which states that "perceived risk of use does not affect the use of information technology in tax administration in Nigeria" is rejected. It is thereby concluded that perceived risk of use does affect the use of information technology in tax administration in Nigeria.

Table 9 shows the model coefficient (that is, the intercept and the slope). From Table 9, the results show that security challenge (t-value $=3.240$, $\mathrm{p}$-value $=0.036$ ) is significant at $5 \%$ level. That is, one additional increase in security challenge faced by taxpayer will affect the use of information technology in tax administration in Nigeria by $26.1 \%$. The results also show that privacy challenge (t-value $=3.240$, $\mathrm{p}$ value $=0.036$ ) is statistically significant at $5 \%$ level. This implies that an increase in privacy challenge will affect the use of information technology in tax administration in Nigeria by $70.2 \%$. These analyses signify that each of the variables has affected the use of information technology by taxpayers in Nigeria. Hence, perceived risk of use does affect the use of information technology in tax administration in Nigeria.

Table 9. Coefficients ${ }^{\mathrm{a}}$

\begin{tabular}{|c|l|l|l|l|l|}
\hline \multirow{2}{*}{ Model } & \multicolumn{2}{|c|}{ Unstandardized Coefficients } & \multicolumn{1}{|c|}{$\begin{array}{c}\text { Standardized } \\
\text { Coefficients }\end{array}$} & Sig. \\
\cline { 2 - 5 } & B & Std. Error & Beta & & \\
\hline \multirow{2}{*}{1} & 0.441 & 0.088 & & 5.007 & 0.000 \\
\hline $\begin{array}{l}\text { (Constant) } \\
\text { Security. } \\
\text { Challenge } \\
\begin{array}{l}\text { Privacy. } \\
\text { Challenge }\end{array}\end{array}$ & 0.247 & 0.038 & 0.261 & 3.240 & 0.036 \\
\hline
\end{tabular}

a. Dependent Variable: Perceived risk of use of information technology

Source: Field Survey, 2018

Research Question 4: To what extent has information technology been accepted in the administration of tax in Nigeria? 
Hypothesis 4 sought to answer research question 4 stated above. In doing this, Pearson correlation is used to explain the relationships that exist among variables, i.e., staff training, attitude, self efficiency and tax administration.

$H_{04}$ : The application of information technology has not been accepted in the administration of tax in Nigeria?

Table 10. Correlations among staff training, attitude, self efficacy and tax administration

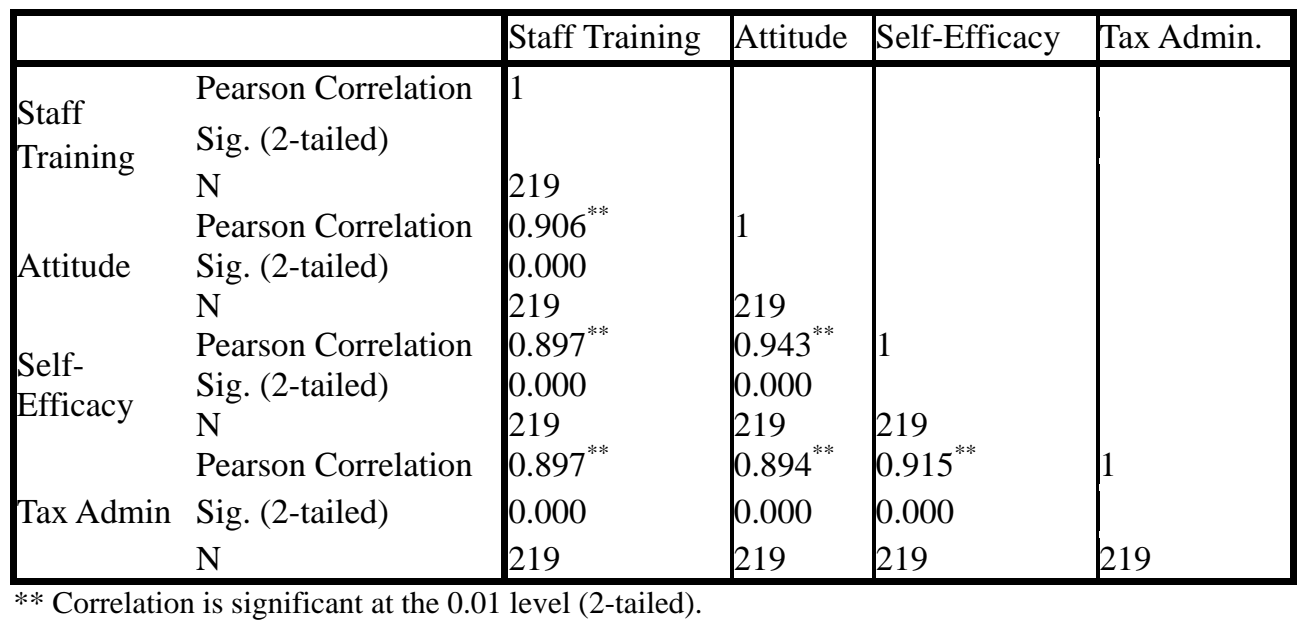

Sources: Field Survey, 2018

A review of Table 10 shows reasonable level of relationships among the acceptability of information technology and tax administration in Nigeria. The correlation values, $r$, varies between 0.894 and $0.915(\mathrm{p}=0.01)$ which are within acceptable limit. This implies that staff training and professional development, selfefficacy and attitude of staff, to a large extent, determine the acceptability of application of information technology in tax administration in Nigeria. Hence the null hypothesis is rejected. 
Issue 1/2019

\section{Discussion of Finding}

Within the existing framework of tax administration by the Federal Inland Revenue Service (FIRS), tax reforms which include Re-engineering and automating collections/tax administration system; Building capacity in the areas of structure, staffing and specialization; and Re-engineering and automating human resource processes, finance and procurement are used to stimulate tax information technology. These are considered to be element of technology innovation; the effectiveness of these elements in improving tax administration was measured in this study. In addition to this, how the use of information technology could enhance tax administration in Nigeria was subsequently considered. To assess if any significant relationship exists between the variables, a regression model fit was obtained from analysis of the questionnaire. Findings show that there is a significant relationship between the use of information technology and tax administration in Nigeria. This is in agreement with the findings of Sabitova and Khafizova (2015) whose study suggested that tax administration would actively use information technologies to improve its performances.

\section{Summary, Conclusion, Contribution to Knowledge and Recommendations Summary of findings}

Tax administration in Nigeria by the Federal Inland Revenue Service (FIRS) hinges on tax reforms which include re-engineering and automated collections/tax administration system; building capacity in the areas of structure, staffing and specialization; and re-engineering and automating human resource processes, finance and procurement. These are used to stimulate tax information technology as they are considered to be element of technology innovation. The effectiveness of these elements in improving tax administration was measured in this study. In addition to this, how the use of information technology could enhance tax administration in Nigeria was subsequently considered. This is in consonance with the studies by a number of authors [Sabitova \& Khafizova, 2015; Guillermo, et al., 2013].

\section{Conclusion}

The goal of tax authorities is to collect the full amount of taxes and duties payable in accordance with the law. Tax authorities should aim at reducing the tax compliance gap while at the same time minimizing the administrative bottleneck of 


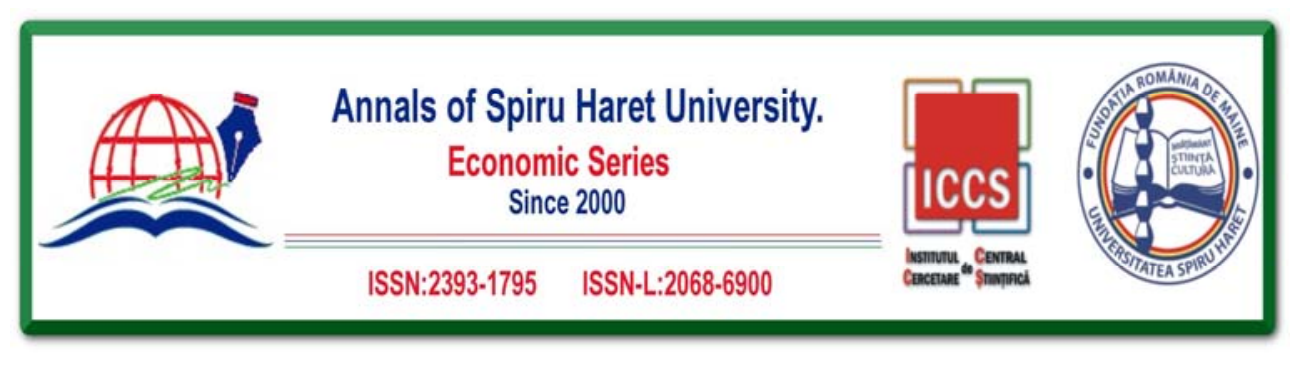

Issue 1/2019

collecting taxes for the government and of paying taxes for taxpayer. This can be done by applying policies to facilitate and stimulate "voluntary compliance". The comparative analysis of tax business in different countries in terms of tax administration revealed that efforts were focused on the comfort conditions for communication between taxpayers and tax authorities. As part of international tax cooperation, the automated information systems are being developed that ensure tax business, facilitate communication at a quality level and exchange the information between the tax authorities worldwide. This study provides empirical evidence that Information Technology has been accepted and improved tax administration in top industries countries. From the regression analysis result on hypothesis one and two, it was found that the $\mathrm{R}$ value is 0.763 , R-square is 0.581 , adjusted R-square is 0.576 and the standard error of estimate is 0.03844 . The large value of $\mathrm{R}$ indicates a stronger relationship between the observed and predicted values of the variables. In other words, the $\mathrm{R}$ value depicts that the use of information technology accounted for 76.3\% improvement in tax administration in Nigeria. This is line with the findings of [Sabitova \& Khafizova, 2015] who posited that most of the industrial countries use electronic filing and online services for providing information to the taxpayers.

\section{Contribution to Knowledge}

The study was able to combine the Theory of Planned Behaviour (TPB) and Technology Acceptance Model (TAM) to empirically evaluate the acceptability of the technology innovation and behavioural intention towards the use of technology in tax administration.

It appears that no published study has employed both TPB and TAM together to evaluate the behavioural intention of taxpayers towards the use of technology in tax administration with the aim of enhancing greater tax compliance which in turn will have incremental effect on the tax revenue generated by the government to perform its functions.

\section{Recommendations}

The following recommendations are made from the findings of this study:

i. Obtaining key stakeholder commitment was the primary challenge for implementation of information technology in tax administration. It is therefore recommended that the commitment of the stakeholder to the use of e-filing is vigorously encouraged; 


\section{Issue 1/2019}

ii. This study recommend a phased-approach for implementation, that is, the implementation would be completed for large taxpayers first and rolled out to other offices at a later date because it is likely to be unsuccessful if insufficient time and planning is given to the rollout.

iii. Tax education should be introduced into the syllabi of schools in Nigeria from the primary schools to the tertiary institutions in Nigeria. This will afford the students the opportunity to understand the importance and benefits derivable from tax through taxation;

iv. Tax authorities should partner with stakeholder to create tax awareness for future taxpayers on the need to use information technology in tax processes through aggressive publicity and advertisement in the print and electronic media;

v. Adequate security should be put in place to guarantee the safety of information supplied electronically by taxpayers; and

vi. Finally there should be persistent training and re-training of the staff of tax authorities, organising workshops and seminars for taxpayers on how to use technology in processing and filing their tax returns.

\section{References}

[1] Adams, D.A., Nelson, R. R., \& Todd, P. A. (1992). "Perceived Usefulness, Ease of Use and Usage of Information Technology: a replication,” MIS Quarterly 16(2), 227-247.

[2] Adeyeye, G. B. The Impact of Taxpayers' Perception of Good Governance on Voluntary Tax Compliance in Lagos State, Nigeria. Unpublished Thesis, Department of Accounting, University of Lagos, Nigeria, 2013.

[3] Ajzen, I. (1991). "Theory of Planned Behaviour." Organizational Behaviour and Human Decision Processes, 50(1), 179-211.

[4] Alabede, J.O., Ariffin, Z.Z. \& Idris, K.M. (2011). "Individual Taxpayers’ Attitude and Compliance Behaviour in Nigeria: The Moderation Role of Financial Condition and Risk Preference.” Journal of Accounting and Taxation, 3(5), 91-104.

[5] Alli, B.D. (2009). "Managing the Tax Reform Process in Nigeria." Niger Account. 42(1), 45-51.

[6] Anyanfo, A.M.O. Public Finance in a Developing Economy: The Nigerian Case. Department of Banking and Finance, University of Nigeria, Enugu Campus. Enugu, 1996.

[7] Bandura, A. (1977). "Self-Efficacy: Toward a Unifying Theory of Behavioural Change," Psychological Review 84(2), 191-215. 


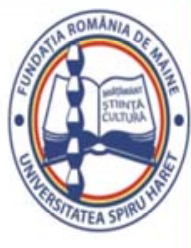

Issue 1/2019

[8] BECANS (2007), Business Environment Report. Enugu, African Institute for Applied Economics 1(15), 10-13.

[9] Berhane, Z. The Influence of Tax Education on Tax Compliance Attitude. Unpublished master's thesis, Addis Ababa University, Ethiopia, 201.

[10] Bobek, D.D. \& Hatfield, R.C. (2003). "An Investigation of the Theory of Planned Behaviour and the Role of Moral Obligation in Tax Compliance.” Behavioural Research in Accounting, 15 (1), 13-38.

[11] Central Bank of Nigeria (CBN) (2011). Annual report and statement of account. Abuja.

[12] Central Bank of Nigeria (CBN) (2013). Statistical Bulletin. Abuja.

[13] Chau, Y. K. \& Hu, J. H. (2001). "Information Technology Acceptance By Individual Professionals: A Model Comparison Approach,” Decision Sciences 32(4), 699-718.

[14] Chin, W.W. \& Gopal, A. (1995). “Adoption Intention in Gss: Relative Importance of Beliefs”, The Data Base for Advances in Information Systems, 26(2/3), 42-64.

[15] Davis, F.D. (1989). "Perceived Usefulness, Perceived Ease of Use, and User Acceptance of Information Technology,” MIS Quarterly 13(3), 319-339.

[16] Davis, F.D., Bagozzi, R.P. \& Warshaw, P.R. (1989). "User Acceptance of Computer Technology: A Comparison of Two Theoretical Models,” Management Science, 35(8), 982-1003.

[17] Edemode, J. (2009). “Towards a People-Focused Tax System in Nigeria: Gauge.” A Quarterly Publication of Federal Inland Revenue Service (FIRS).

[18] Federal Inland Revenue Service (2012). Excerpts of the Handbook - Federal Inland Revenue Service and Taxation Reforms in Democratic Nigeria.

[19] Federal Inland Revenue Service (2013). Tax Benefits. Retrieved November 14, 2013, from http://www.firs.gov.ng/Tax-Management/Pages/Tax-Benefits.aspx.

[20] Federal Ministry of Finance. National Tax Policy: Federal Ministry of Finance, Abuja, 2016.

[21] Federal Ministry of Finance. National Tax Policy: Federal Ministry of Finance, Abuja, 2012.

[22] Fu, J.R., Farn, C.K., \& Chao, W.P. (2006). “Acceptance of Electronic Tax Filing: A Study of Taxpayer Intentions.” Journal of Information \& Management 43(1), 109-126

[23] Guillermo, J., Niall, M. \& Anton, K. S. (2013). Information Technology for Tax Administration. USAID Leadership in Public Financial Management (LPFM) Sponsoring USAID Office: USAID/Mission Contract Number: EEM-I-00-07-00005-00 Contractor: Deloitte Consulting LLP February 2013 Date of Publication.

[24] Heijden, H., Van der, V.T. \& Creemers, M. (2001). "Predicting Online Purchase Behaviour: Replications and Test of Competing Models", in: Proceedings of the 34th Hawaii International Conference System Science, Maui, Hi. 


\section{Issue 1/2019}

[25] Hoffman, D., Novak, T. and Peralta, M. (1999). "Building Consumer Trust Online,” Communications of the ACM 14(2), 80-85.

[26] Hsu, T.H., Wang, Y.S. \& Wen, S.C. (2006). "Using the Decomposed Theory Of Planned Behaviour To Analyse Consumer Behavioural Intention Towards Mobile Text Message Coupons”, Journal of Targeting, Measurement and Analysis for Marketing, 14 (4), 309-24.

[27] Hung, S.Y., Chang, C.M. \& Yu, T.J. (2006). "Determinants of User Acceptance of the E-Government Services: the case of online tax filing and payment system”, Government Information Quarterly, 23(1), 97-122.

[28] Institute of Chartered Accountants of Nigeria (ICAN) (2009), Taxation Study Pack, Lagos: VI Publishers.

[29] Institute of Chartered Accountants of Nigeria (ICAN) (2010), Taxation Study Pack, Lagos: VI Publishers.

[30] Kothari, C.R. Research Methodology Methods and Techniques. New Delhi: New Age International (P) Limited, 2004.

[31] Lee, M. C. (2008). "Factors Influencing the Adoption of Internet Banking: An Integration of TAM and TPB with Perceived Risk and Perceived Benefit.” Electronic Commerce Research and Applications 12(1), 303.

[32] Lu, H. P., Gustafson, D. H. (1994). “An Empirical Study of Perceived Usefulness and Perceived Ease of Use on Computerized Support System Use Over Time,” International Journal of Information Management 14(5), 317-329.

[33] Mukasa, J. Tax Knowledge, Perceived Tax Fairness and Tax Compliance in Uganda. Unpublished Master Thesis. Makerere University, Kampala, Uganda, 2011.

[34] Nel, M.J. An Analysis of the Compliance Approach Used By Revenue Authorities with Specific Reference to Case Selection and Risk Profiling. Unpublished master's thesis, Rhodes University, Grahamstown, South Africa, 2004.

[35] Nelson, G. (2002). "Information Technology in Support of the Tax Administration Functions and Taxpayer Assistance.” 3(5), 2-11.

[36] Nzotta, S.M., (2007). “Tax Evasion Problems in Nigeria: A Critique.” Nigerian Accountants 40(2), 40-43.

[37] Odusola, A., (2006). Tax Policy Reforms in Nigeria. United Nations University-World Institute for Development Economics Research. Research Paper No. 2006/03.

[38] Ogbonna, G.N. \& Appah, E. (2012). "Impact of Tax Reforms and Economic Growth of Nigeria: A Time Series Analysis.” Journal of Social Sciences 4(1), 62-68.

[39] Ogundele, A.E. Elements of Taxation ( $1^{\text {st }}$ Ed.). Lagos, Libri Services Nigeria Limited, 1999.

[40] Omolehinwa, E. O. \& Naiyeju, J. K. Theory \& Practice of Government Accounting in Nigeria, Lagos: Punmark Nigeria Limited, 2011. 


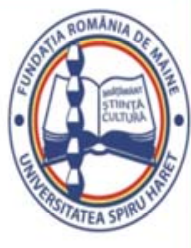

Issue 1/2019

[41] Organisation for Economic Cooperation and Development (OECD). Compliance Measurement - Practice note. Paris: Central for Tax Policy and administration, 2011.

[42] Paul, L. and John, I. (2003). "Why Do People Use Information Technology?” A critical review of the technology acceptance model Information and Management 40(3), 191-204.

[43] Riemenschneider, C. K. Harrison, D.A. \& Mykytyn, P. P. (2003). "Understanding IT Adoption Decisions in Small Business: integrating current theories," Information and Management 40(1), 269-285.

[44] Rogers, E.M. The Diffusion of Innovation (4th ed.), Free Press, New York, 1985.

[45] Sabitova N. M. and Khafizova A. R. (2015). "Information Technology as Factor of Evolution Tax Administration.” Mediterranean Journal of Social Science; MCSER Publishing, Rome, 6(1), 1 - 5 .

[46] Soyode, L. \& Kajola, S.O. Taxation: Principles and Practice in Nigeria ( ${ }^{\text {st }}$ Ed.), Ibadan: Silicon, 2006.

[47] Tarkiainen, A. \& Sundqvist, S. (2005). "Subjective Norms, Attitudes and Intentions of Finnish Consumers in Buying Organic Food.” British Food Journal, 107 (10-11), 808-822.

[48] Taylor, S. \& Todd, P.A. (1995). "Understanding Information Technology Usage: A Test of Competing Models,” Information Systems Research 6(2), 144-176.

[49] Tosun, M.S. \& Abizadeh, S. (2005). "Economic Growth and Tax Components: An Analysis of Tax Change in OECD.” Appl. Econ., 3(7), 2251-2263.

[50] Triandis, H.C. Interpersonal Behaviour, Brooks/Cole, Monterey, CA, 1977.

[51] Venkatesh, V. (2000). "Determinants of Perceived Ease of Use: Integrating Control, Intrinsic Motivation, and Emotion into the Technology Acceptance Model,” Information Systems Research 11(4), 342-365.

[52] Venkatesh, V. and Davis, F.D. (2000). “A Theoretical Extension of the Technology Acceptance Model: Four Longitudinal Field Studies,” Management Science 46(2), 186204.

[53] Venkatesh, V., Morris, M.G. \& David, G.B. (2003). “User Acceptance of Information Technology: Toward a Unified View”, MIS Quarterly 27(3), 425-478.

[54] Wang, Y. S. (2002). “The Adoption of Electronic Tax Filing Systems: An Empirical Study,” Government Information Quarterly, Changhua 20(1), 333-352.

[55] West Group. Black's Law Dictionary ( $7^{\text {th }}$ Ed.), 1999.

[56] Wu, J. H., Wang, S. C. \& Lin, L. M. (2007). "Mobile Computing Acceptance Factors in the Healthcare Industry: A Structural Equation Model," International Journal of Medical Informatics, 76(1), 66-77. 
